\title{
Drought Tolerance in Digitaria
}

\author{
A. J. Oakes and W. R. Langford ${ }^{1}$
}

\section{INTRODUCTION}

Pangola grass (6), ${ }^{2}$ Digitaria decumbens Stent, is widely used as a pasture grass at lower elevations throughout the Tropics and Subtropics. Low temperatures associated with increased elevation limit its production area in the Tropics and Subtropics, as do vast arid areas of inadequate or poorly distributed rainfall. Its production area in the Subtropics of the Northern and Southern Hemispheres is limited by low temperatures during the winter months. Reports on the cold tolerance and winter survival of Pangola grass have been made $(3,8,9,10)$, although little information is reported on its drought tolerance. The drought tolerance of Pangola grass has not been fully explained. A study of its root system failed to explain its drought tolerance (7). Burton, DeVane, and Carter (1) failed to establish a significant relationship between root weight, penetration, and fertilizer uptake.

Genetic diversity in the Digitaria collection in the American Tropics and Subtropics was increased by a collection made by the U.S. Department of Agriculture in South Africa in 1964 (4). The discovery and utilization of drought-tolerant germ plasm in Digitaria species will increase their production range and livestock-carrying capacity, and extend the effective grazing period-all of which contribute to higher yields of livestock and livestock products. The objective of this study was to evaluate selected clones of Digitaria for drought tolerance in field trials.

\section{MATERIALS AND METHODS}

Selected clones of Digitaria were evaluated for drought tolerance in field trials in Puerto Rico. The trials were located in a tropical climate to avoid confounding drought tolerance with cold tolerance. The Department of

1 Research Agronomist and Agronomist, Crops Research Division, Agricultural Research Service, USDA, Beltsville, Maryland, and Experiment, Georgia, respectively.

Appreciation is expressed to the Department of Agriculture, Commonwealth of Puerto Rico, for permission of land use in Guánica State Park. The authors wish to thank Dr. Murray Gaskins, Officer in Charge, Federal Experiment Station, Mayagüez, P.R., for his interest and assistance in this research. Special thanks are due Sr. Narciso Almeyda, Agricultural Research Technician, who assisted in the field work. Dr. J. Vélez-Fortuño, Jirector, Plant Breeding Department, Agricultural Experiment Station, Mayagüez Campus, University of Puerto Rico, Río Piedras, P.R., kindly furnished some of the propagating stocks.

2 Italic numbers in parent heses refer to Literature Cited, p. 69. 
Agriculture, Commonwealth of Puerto Rico, granted permission for use of a planting site in the Guanica State Forest, a very dry area of the southwestern portion of the Island.

The planting was located near the sea, about 20 feet above sea level, where it was stibject to the effects of prevailing desiccating trade winds (fig. 1). The limestone rock soil is shallow, dry, and low in water-holding capacity; it has been described previously (2). Indigenous flora of the area is characterized by low-growing chaparral, comprised mainly of Acacia, Bursera, Cactus, and Opuntia species. Hurricanegrass, a botanical form

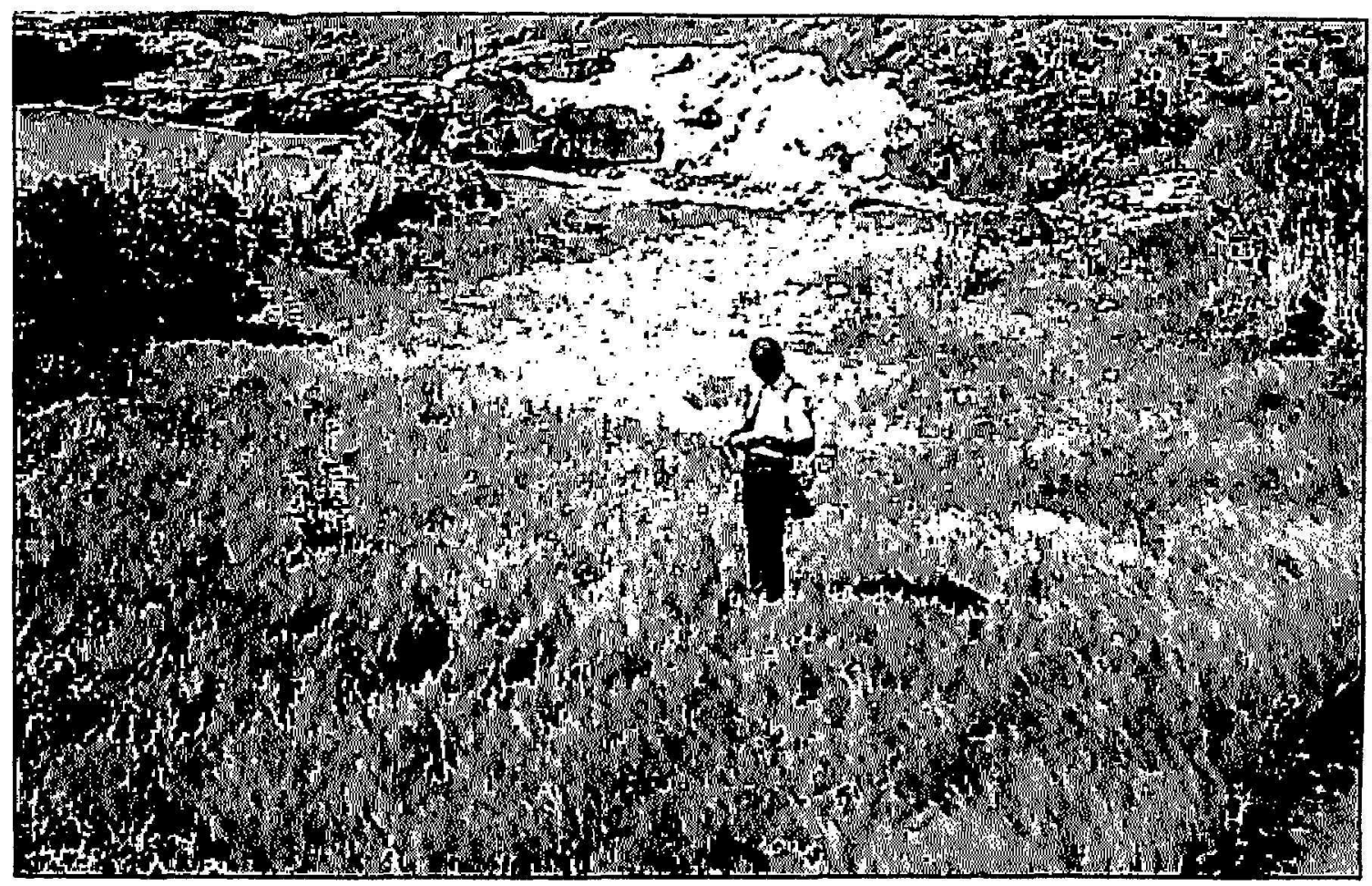

FIG. 1.-View of planting site.

of Bothriochloa pertusa (L.) A. Camus, occurs in scattered open areas and along trails and roads.

Fifty-nine-year average annual rainfall at Ensenada, Puerto Rico, nearest recording station to the planting site, is 30.4 inches, most of which occurs during September-December (11). Open-pan evaporation at a nearby station, Lajas, Puerto Rico, exceeds 80 inches per annum.

Vegetative propagating stocks were supplied by the University of Puerto Rico and by the Southern Regional Plant Introduction Station, Experiment, Georgia. Sixty-two plants, representing 29 clones of 10 Digitaria species, were planted (table 1). Clones were selected for evaluation representing species on which drought tolerance and desirable agronomic characteristics have been reported, and on our observations of their behavior 
TABLe 1.-Drought tolerance in Digitaria species grown for $\&$ years in Guanica State Forest, Puerto Rico

\begin{tabular}{|c|c|c|c|c|c|c|}
\hline \multirow[t]{2}{*}{ Species and P.I. No.1 of clomes planbled } & \multirow{2}{*}{$\frac{\begin{array}{c}\text { Plonts } \\
\text { planted }\end{array}}{\text { Number }}$} & \multicolumn{5}{|c|}{ Survioal rating } \\
\hline & & $\begin{array}{l}\text { Jasruary } \\
\text { log8 }\end{array}$ & $\begin{array}{l}\text { Seplember } \\
1968\end{array}$ & $\begin{array}{l}\text { September } \\
1969\end{array}$ & $\begin{array}{l}\text { Slabi } \\
\text { sign: }\end{array}$ & istically \\
\hline \multicolumn{7}{|l|}{ D. decumbens Stent } \\
\hline $\begin{array}{l}111110 \text { Pangola grass } \\
\text { D. setivalva Stent }\end{array}$ & 2 & 3.0 & 4.0 & 4.0 & \multicolumn{2}{|c|}{$3.7 \mathrm{a}$} \\
\hline 299795 & 2 & 3.0 & 4.0 & 4.0 & \multicolumn{2}{|c|}{$3.7 \mathrm{a}$} \\
\hline D. valida Stent & & & & & & \\
\hline $\begin{array}{c}299850,299858 \\
\text { D. decumbens Stent }\end{array}$ & 4 & 2.3 & 4.0 & 4.0 & \multicolumn{2}{|c|}{$3.4 \mathrm{ab}$} \\
\hline $299601,299602,299837$ & 6 & 2.0 & 3.3 & 3.3 & \\
\hline $\begin{array}{l}\text { D. smutsii Stent } \\
\text { D. pentzii }\end{array}$ & 4 & 2.2 & 3.2 & 2.7 & \multicolumn{2}{|c|}{$\begin{array}{l}2.9 \text { abc } \\
2.7 \text { bcd }\end{array}$} \\
\hline $\begin{array}{l}\text { var. stolonifera (Stapf) Hear. } \\
299799\end{array}$ & 2 & 2.0 & 2.5 & $\mathbf{3 . 0}$ & \multicolumn{2}{|c|}{2.5 bed } \\
\hline \multicolumn{7}{|l|}{ D. pentzii Stent } \\
\hline $\begin{array}{l}\text { 299743, 299753, } 299763 \\
\text { D. milanjiana (Rendle) Stapf }\end{array}$ & 6 & 1.8 & 2.5 & 2.7 & 2.3 & cde \\
\hline $\begin{array}{l}299655,299667,299675,299676 \\
299689,299690,299699\end{array}$ & 16 & 1.9 & 2.4 & 2.1 & 2.1 & cdef \\
\hline $\begin{array}{l}\text { D. milanjiana } \\
\text { subsp. eylesiana Henr. 299708, } \\
299736\end{array}$ & 4 & 1.5 & 2.5 & 1.0 & 1.7 & def \\
\hline $\begin{array}{l}\text { D. setivalva Stent } \\
299796,299799,299802\end{array}$ & 8 & 1.8 & 2.1 & 1.3 & 1.7 & def \\
\hline $\begin{array}{l}\text { D. diversinervis (Nees) Stapf } \\
299610,299613\end{array}$ & 4 & 2.2 & 1.0 & 1.0 & 1.4 & efg \\
\hline D. swazilandensis Stent & & & & & & \\
\hline 299838 & 2 & 1.0 & 1.5 & 1.0 & 1.2 & fg \\
\hline $\begin{array}{l}298648 \\
\text { Mean }\end{array}$ & 2 & $\begin{array}{l}1.0 \\
2.0 \mathrm{~b}\end{array}$ & $\begin{array}{l}1.0 \\
2.6 \mathrm{a}\end{array}$ & $\begin{array}{l}0.1 \\
2.3 \text { \& }\end{array}$ & 0.7 & $\mathbf{g}$ \\
\hline
\end{tabular}

1 USDA Plant Introduction number.

2 0-No survival; 1-Weak, no apparent growth; 2-Intermediate, some growth apparent; 3-Vigorous, original plant exhibits intermediate growth; 4-Vigorous and spreading.

3 Means are significantly different at 5-percent level by Duncan's multiple range if not followed by any letters in common.

when grown elsewhere. All species included in these trials, except Digitaria macroglossa Henr., are characterized by stoloniferous growth habit. Individual clones, considered as separate plant introductions by the U.S. Department of Agriculture, were assigned USDA Plant Introduction numbers. Pangola grass $(D$. decumbens, USDA Plant Introduction Number 111110) was used as the standard by which all clones were compared. 
Unstripped stolons containing leaves were used for propagating stocks. Rhizomes were used to establish $D$. macroglossa. Stolons were planted in 6-inch holes, spaced 4 to 6 feet apart in 4-foot rows. This spacing provided sufficient area for growth so that the clones would remain separate and identifiable throughout the duration of the trials. Equivalent quantities of propagating stocks of each clone were used and equal portions of each planting remained above and below the soil surface during the planting operation. These precautions were taken to insure equal opportunity of establishment and growth of all stocks planted. The soil was cup-shaped around each planting to insure moisture retention. The soil was completely dry on the surface when the planting was made, and the plants were watered immediately after the planting was completed. The grass was planted October 3, 1967. Plant survival readings were made and recorded in January and September 1968, and September 1969.

\section{RESULTS AND DISCUSSION}

The dry climate, characteristic of the southwestern coast of Puerto Rico, and the shallow, dry soil, low in water-holding capacity, are conducive to inefficient use of available moisture. Rainfall data from Ensenada, Puerto Rico, a few miles from the trial site, show 6.1 inches of rainfall occurred during the month (September) preceding planting. The rainfall was 5.5 inches for the 3-month interim following planting, with only 0.8 inch occurring in December-January. The recorded rainfall was 20.5 inches for 1968, and only 10.8 inches of rain fell during January-October, inclusive, 1969. Only 36.8 inches of rainfall was recorded for the duration of the trials, i.e., 25 months.

Approximately 34 percent of the plants failed to survive for 2 years. Four plants were lost during the crucial 3-month period subsequent to planting. Four more plants were lost during the ensuing dry season of 1968 , and 13 additional plants failed to survive the second dry season (1969).

Data in table 1 show differential survival and growth occurred among species and clones. Clones of $D$. decumbens, $D$. setivalva Stent, and $D$. valida Stent rank highest in survival value.

Pangola grass is pantropic and it is planted more extensively than any other representative of the genus, especially in the American Tropics. The control, Digitaria decumbens (P.I. 111110, Pangola grass), performed remarkably well in comparison with all other clones (table 1). The drought tolerance of pangola grass has not been adequately explained, whether grown in pure ( 7$)$ or in mixed stands (5). Pangola grass was established successfully during the dry season on a heavy clay soil in the U.S. Virgin Islands, 
where it received only 5.3 inches of rainfall for 3 months following planting. ${ }^{8}$ The performance of three other clones of $D$. decumbens is indicative of the drought tolerance of this species. Data in table 1 show that $D$. decumbens is superior to $D$. diversinervis (Nees) Stapf, $D$. macroglossa Henr., $D$. setivalva Stent, $D$. swazilandensis Stent, and $D$. milanjiana subsp. eylesiana Henr. During droughty periods, Pangola grass appears greyish-green in color, becoming dark green with the addition of moisture. During sustained periods of extreme drought, the leaves roll tightly inward and the plants appear to cease active growth and stolon elongation.

Selected clones of $D$. valida Stent demonstrate high potential for pasturage and erosion control; fertile clones are being used in plant-breeding techniques in plant improvement programs. Clones of $D$. diversinervis, $D$. macroglossa, and $D$. swazilandensis demonstrate low survival value (table 1 ). Selected clones of the strongly rhizomatous species, $D$. macroglossa, possess good soil- and sand-binding capacity and are being evaluated in dune stabilization. Some clones of $D$. smutsii Stent are heavy seed producers; this species contains considerable cold-tolerant germ plasm.

The differential performance of individual clones within a species is best demonstrated by $D$. setivalva. The clone P.I. 299795 is outstanding in drought resistance; its performance was superior to the average performance of three other clones of this species (table 1). This clone initiated growth and increased at a rate comparable to that of Pangola grass. Although generalizations may be made with a reasonable degree of assurance regarding comparative performance among species, these results suggest that more emphasis should be placed on outstanding individual clones in considering survival behavior among species.

Initial observations on survival and growth were made 3 months after planting; similar observations were made in September 1968, and again a year later. The average survival rating made 3 months after planting is significantly less than that of subsequent ratings; however, the early readings are indicative, to a reasonable degree, of the subsequent performance of the grasses (table 1). The average performance of the grasses for 1968 and 1969 is not significantly different (table 1). The loss of 13 clones during the second dry season may be explained in part by the low rainfall for 1969. Differences in performance among Digitaria species were significant and consistent. They were ranked about the same for three rating periods. Observations made on survival and growth a few months after planting may be considered reliable criteria for subsequent performance of these grasses.

8 Virgin Islands Agricultural Program Quart. Rep. for April-June 1953 (unpublished). 
Well over one-half of the plants survived and exhibited variable amounts of growth and aggressiveness. These results suggest two possible interpretations. Firstly, Digitaria species included in this trial exhibited drought tolerance under field conditions unknown or unreported. Secondly, perhaps drought stress was not severe enough to further differentiate survival value among species and clones. The results suggest that further differentiation among species and clones for survival value may have been achieved, provided the environmental conditions had been more severe; i.e., lack of rainfall, from the standpoint of promoting plant growth and survival. Clones which failed apparently were not established well enough to survive the severe drought of 1969. These results suggest the need for additional study to further delineate the drought-resistant germ plasm in Digitaria.

\section{SUMMARY}

Selected clones of 10 Digitaria species were evaluated for drought tolerance in field trials. Grasses were established by vegetative propagation during the wet season. Observations on survival and growth were made at intervals throughout the 25-month duration of the trial. Approximately one-third of the plants failed to survive, with greatest losses occurring during the period of minimum rainfall. Significant differences in survival among species were found; for example, Digitaria decumbens Stent and Digitaria valida Stent are superior to Digitaria diversinervis (Nees) Stapf and Digitaria swazilandensis Stent. Differential performance of clones within species is demonstrated by two accessions; i.e., USDA P.I. 111110 (Digitaria decumbens Stent) and USDA P.I. 299795 (Digitaria setivalva Stent). Pangola grass and select clones of other Digitaria species may be established by vegetative propagation in rainfall belts of 20 to 30 inches per annum with reasonable assurance of success.

\section{RESUMEN}

Clones seleccionados de 10 especies de Digitaria se evaluaron en pruebas de campo para determinar su tolerancia a los períodos de sequía. Durante la estación lluviosa, las yerbas se establecieron mediante la propagación vegetativa. Durante los 25 meses que se extendieron las pruebas, se hicieron observaciones a intervalos respecto a la supervivencia y crecimiento de estas yerbas. Alrededor de una tercera parte de las plantas no pudieron sobrevivir, registrándose las pérdidas mayores durante el período de menor precipitación pluvial. Entre las especies se encontraron diferencias significativas en cuanto a su supervivencia. Las diferencias en el comportamiento de clones de una misma especie, se demostraron en dos accesiones, a saber, USDA P.I. 111110 (Digitaria decumbes Stent) y USDA P.I. 299795 (Digitaria setivalva Stent). La yerba Pangola y clones selectos de otras especies 
de Digitaria pueden establecerse mediante la propagación vegetativa en zonas de 20 a 30 inches de lluvia al año con una posibilidad razonable de éxito.

\section{LITERATURE CITED}

1. Burton, Glen W., DeVane, E. H., and Carter, R. L., Root penetration, distribution, and activity in southern grasses measured in yields, drought symptoms and $\mathrm{P}^{32}$ uptake, Agron. J. 46(5): 229-33, 1954.

2. Carter, Oliver R., Soil survey of the Lajas Valley Area, Puerto Rico, Soil Conserv. Serv., USDA and Univ. P.R., Ser. 1961, No. 23, 170 pp., 1965.

3. Dunavin, L. S., Jr., The evaluation of cold hardiness in Florida pasture grasses, Soil and Crop Sci. Soc. Fla. Proc. 19: 172-78, 1959.

4. Oakes, A. J., Digitaria collection from South Africa, Trop. Agr. 42(4): 323-31, 1965.

5. - Replacing hurricanegrass in pastures of the dry Tropics, Trop. Agr. $45(3)$ : 235-41, 1968.

6. - Pangolagrass (Digitaria decumbens Stent), Crop. Sci. $9(6): 835,1969$.

7. Oakes, A. J., Bond, R. M., and Skov, O., Pangolagrass (Digitaria decumbens Stent) in the United States Virgin Islands, Trop. Agr. 36 (2): 130-37, 1959.

8. Oakes, A. J. and Langford, W. R., Cold tolerance in Digitaria, Agron. J. 59(4): 387-88, 1967.

9. Ruelke, O. Charles, Winter injury of Florida's pastures, Soil and Crop Sci. Soc. Fla. Proc. 28: 194-98, 1963.

10. - Potassium fertilization influence on winter survival of pangolagrass, Soil and Crop Sci. Soc. Fla. Proc. 26 : 231-38, 1966.

11. U.S. Weather Bureau, Climatography of the United States No. 86-45, Puerto Rico and United States Virgin Islands, p. 5, Washington, D.C., 1965. 